\title{
MicroRNAs and PIWI-interacting RNAs in oncology (Review)
}

\author{
YONG LIU \\ Department of Neurology, Xuzhou Central Hospital, The Affiliated Xuzhou Hospital of Medical College \\ of Southeast University, Xuzhou, Jiangsu 221009, P.R. China
}

Received April 22, 2016; Accepted July 28, 2016

DOI: $10.3892 / \mathrm{ol} .2016 .4996$

\begin{abstract}
RNA molecules that are unable to translate into proteins are classified as non-coding RNA. Non-coding RNA (ncRNA) genes include highly abundant and functionally important RNAs such as transfer RNAs, microRNAs (miRNAs), siRNAs, snRNAs, exRNAs and piRNAs. The number of ncRNAs encoded within the human genome is unknown; however, recent transcriptomic and bioinformatic studies suggest the existence of thousands of ncRNAs. Furthermore, small ncRNAs, including miRNAs and PIWI-interacting RNAs (piRNAs), play an imperative role in the regulation of gene expression of numerous biological and pathological processes. Investigation into the expression and function of small RNA in cancer cells has contributed to gaining a greater understanding of the roles of small RNAs in carcinogenesis. The present review is aimed primarily to discuss the importance of the expression and functions of these small RNAs in carcinogenesis. These studies may provide useful information for future therapies in cancer.
\end{abstract}

\section{Contents}

1. Introduction

2. Functional roles of miRNAs in cancer

3. Oncogenic miRNAs

4. Tumor suppressor miRNAs

5. Deregulation of miRNAs in adrenocortical tumors

6. Deregulation of miRNAs in testicular germ cell tumors

7. Biological roles of PIWI-interacting RNAs (piRNAs)

8. Maternal mRNA decay during maternal-to-zygotic transition

9. piRNAs in cancer

10. Conclusion

Correspondence to: Dr Yong Liu, Department of Neurology, Xuzhou Central Hospital, The Affiliated Xuzhou Hospital of Medical College of Southeast University, 199 Jiefang Road, Xuzhou, Jiangsu 221009, P.R. China

E-mail: 403627437@qq.com

Key words: microRNAs, PIWI-interacting RNAs, cancer

\section{Introduction}

MicroRNAs (miRNAs) have been observed to be deregulated in numerous diseases, including cancer (1). One of the key mechanisms responsible for this miRNA deregulation is the dysfunctional miRNA biogenesis factor (2). In several human cancer types, the deregulated expression of miRNA machinery has been reported. For instance, approximately $60 \%$ of ovarian cancer patients show a decreased expression of Dicer and Drosha mRNAs and a low expression of Dicer is correlated with advanced tumor stage (3). Mutations of miRNA processing genes have been observed in human cancers, e.g., TARBP2 and exportin-5 in microsatellite unstable colon tumors $(4,5)$, Dicerl in pleuropulmonary blastomas (6) and Drosha in Wilms' tumors (7). In addition, the conditional deletion of Dicerl led to an elevation in tumor development by alteration of the miRNA expression profile in mouse models (8).

Another mechanism underlying deregulated miRNA expression is due to the transcriptional deregulation of miRNA genes. An example is the increased expression of the oncogenic miR-17-92 cluster by c-Myc (9). In addition to c-Myc, p53 and HIF transcription factors are known to regulate the transcription of a number of miRNA genes (10). Epigenetic changes, such as DNA methylation and histone modifications, potentially affect the transcription of miRNA genes in cancer, e.g., hypermethylation of $m i R-337, m i R-432$, and $m i R-371$ have been often observed in ovarian cancer (11). The epigenetic silencing of $m i R-15 a, m i R-16$ and $m i R-29 b$ by histone deacetylases was reported recently in chronic lymphocytic leukemia (CLL) (12).

Another main contributor of miRNA deregulation in cancer is the copy number abnormalities of miRNA genes. One classical example is the deletion of miR-16 and $m i R-15 a$ at $13 \mathrm{q} 14$ in CLL patients, in which approximately $60 \%$ of the patients had deletions of these miRNA genes (13). Mutations present within the miRNA genes and RNA editing of the pri- or pre-miRNA transcripts may also affect their processing $(14,15)$.

\section{Functional roles of miRNAs in cancer}

Cancer is a multistep complex disease, characterized by multiple hallmark traits, as suggested by Hanahan and Weinberg (16). These characteristics include sustaining proliferative signaling, evading growth suppressors, resisting cell death, enabling the stimulation of angiogenesis, invasion of tissue, metastasis, replicative immortality, deregulation of cellular metabolism, elevation in inflammation, instability in genome and immune 
compromises. In addition, the crosstalk between cancer cells and the tumor microenvironment is necessary to orchestrate these hallmarks (17). It is now clear that miRNAs are involved in all the hallmarks of the cancer phenotypes. miRNAs may therefore function as oncogenic or tumor suppressive miRNAs depending on cellular context.

\section{Oncogenic miRNAs}

The first identified oncogenic miRNAs belonged to the miR-17-92 cluster (9). Previous findings have shown the contribution of the deregulation of $m i R-17-92$ in cancer through multiple pathways, such as metastasis and senescence $(18,19)$. Notably, inhibition of this cluster in cervical cancer led to elevated oncogenic activity of E2F1, suggesting its tumor suppressive activity is dependent on cellular context. Another well-studied oncogenic miRNA is $m i R-21$. This miRNA is highly expressed in breast cancer (20), lung cancer (21), glioblastoma (22), adrenocortical and testicular germ cell tumors $(23,24)$. Functionally, $m i R-21$ is known to regulate multiple tumor suppressor genes, such as $P D C D 4$, PTEN and TPM1 (25).

$m i R-155$ is processed from the non-coding RNA (ncRNA) B-cell integration cluster $(B I C)$, which is highly expressed in activated $\mathrm{B}$ and $\mathrm{T}$ cells, and in monocytes/macrophages. This miRNA plays an important role in hematopoiesis and its increased expression is observed in hematological malignancies (26). In addition, high levels of $m i R-155$ are present in solid tumors, such as breast, prostate, gastric, colon and lung cancers $(27,28)$. $m i R-155$ is also involved in the regulation of multiple targets involved in different cancer phenotypes, such as TP53INP1 in apoptosis (29), VHL in angiogenesis (30), and ELK3 in hypoxia (31).

\section{Tumor suppressor miRNAs}

The first characterized tumor suppressor miRNAs were $m i R-16$ and $m i R-15 a$ in B-cell CLL. These miRNAs were significantly downregulated in approximately $60 \%$ of CLL patients due to the deletion of the $13 q 14$ region where these miRNAs reside (32). Deletion of this locus and a decreased expression of these miRNAs have been reported in other cancer types, such as lung (33) and prostate cancers (34). miR-15a/16 inhibit cell proliferation and tumor growth by targeting CCNDI and CCNE1 (35), and promote apoptosis by targeting the anti-apoptotic factor BCL2 (36).

\section{Deregulation of miRNAs in adrenocortical tumors}

Several miRNAs have been observed to be differentially expressed and recognized between malignant and benign adrenocortical tumors. $m i R-483-3 p$ and $m i R-483-5 p$ are consistently overexpressed in adrenocortical carcinoma (ACC) (37). $m i R-483$ resides within the intron of insulin-like growth factor 2 (IGF2), which is overexpressed in approximately $80 \%$ of ACC (23). It has been shown that under hypoxic condition, the expression of $m i R-210$ was induced by HIF1a, which in turn leads to the suppression of $M N T$, which antagonizes the oncogenic function of MYC (38). Overexpression of $m i R-503$ was correlated with short overall survival.
On the other hand, a decreased expression of $m i R-195$ and $m i R-497$ was consistently reported in several studies $(37,39)$. The overexpression of $m i R-195$ or $m i R-497$ suppresses cell proliferation and induces cell death in ACC cells. Of note, $m i R-195$ and $m i R-497$ regulate TARBP 2 and Dicer in ACC (40).

\section{Deregulation of miRNAs in testicular germ cell tumors}

A growing number of differentially expressed miRNAs have been identified in testicular germ cell tumors (TGCTs). One of the first characterized oncogenic miRNAs in TGCTs was the $m i R-372-373$ cluster, which is known to be involved in inducing oncogenic stress, which in turn allow cells to become malignant (41).

$m i R-199 a$ expression is observed to be decreased in TGCTs, and its putative oncogenic target v-maf musculoaponeurotic fibrosarcoma oncogene family, protein $\mathrm{B}(M A F B)$ has been identified in TGCTs (42).

\section{Biological roles of PIWI-interacting RNAs (piRNAs)}

In silkworm, the male phenotype is determined by the presence of two $\mathrm{Z}$ chromosomes, whereas the female phenotype is established by having $\mathrm{Z}$ and $\mathrm{W}$ chromosomes (43). The gender determining region of $\mathrm{W}$ chromosome expresses a piRNA precursor, which is processed into gender determining piRNA, termed fem piRNA. This piRNA specifically recognizes the masculinization (Masc) mRNA and degrades the transcript, suggesting its role in gender determination (43).

During late spermatogenesis, the majority of mRNAs are eliminated in the elongating spermatids; thus, mature sperms retain only few mRNAs (44). It has been recently shown that elimination of these mRNAs in the elongating spermatids requires the activity of MIWI-bound piRNAs, which recruits CAF1 deadenylase complex for their further turnover (44).

\section{Maternal mRNA decay during maternal-to-zygotic transition}

During maternal-to-zygotic transition, the majority of maternal mRNAs are degraded and replaced by zygotic mRNAs. It has been shown that, in Drosophila melanogaster, piRNAs mediate the elimination of maternal nanos mRNAs during this transition (45). The degradation of nanos mRNA by piRISC is mediated by a similar mechanism as that described above.

\section{9. piRNAs in cancer}

The functions of piRNAs and PIWI proteins have started to emerge in human cancers. The deregulated expression of PIWI proteins has been reported in several human tumors, including human seminoma (46), breast, liver, gastric and cervical cancers (47). An increased expression of HIWI is correlated with invasion in cervical cancer and poor prognosis in glioma patients (48).

In addition to the expression of PIWI proteins, deregulated expression of piRNAs has been reported in human cancers, including breast cancer (49), bladder cancer (50), multiple myeloma (51), endometrial cancer (52) and gastric 
cancer (53). The functional role of specific piRNAs in human cancer is poorly understood. Only piR-823 is currently known to regulate de novo DNA methylation and angiogenesis in multiple myeloma (51).

\section{Conclusion}

The abovementioned studies indicate that investigations focus on exploration of the importance of ncRNAs in cancer. These studies are likely to result in better treatment strategies based on these ncRNA interactions in future.

\section{References}

1. Sand M, Bechara FG, Sand D, Gambichler T, Hahn SA Bromba M, Stockfleth E and Hessam S: Expression profiles of long noncoding RNAs in cutaneous squamous cell carcinoma. Epigenomics 8: 501-518, 2016.

2. Ouellet DL, Perron MP, Gobeil LA, Plante P and Provost P: MicroRNAs in gene regulation: when the smallest governs it all. J Biomed Biotechnol 2006: 69616, 2006.

3. Merritt WM, Lin YG, Han LY, Kamat AA, Spannuth WA, Schmandt R, Urbauer D, Pennacchio LA, Cheng JF, Nick AM, et al: Dicer, Drosha, and outcomes in patients with ovarian cancer. N Engl J Med 359: 2641-2650, 2008.

4. Melo SA, Moutinho C, Ropero S, Calin GA, Rossi S, Spizzo R, Fernandez AF, Davalos V, Villanueva A, Montoya G, et al: A genetic defect in exportin-5 traps precursor microRNAs in the nucleus of cancer cells. Cancer Cell 18: 303-315, 2010.

5. Melo SA, Ropero S, Moutinho C, Aaltonen LA, Yamamoto H, Calin GA, Rossi S, Fernandez AF, Carneiro F, Oliveira C, et al: A TARBP 2 mutation in human cancer impairs microRNA processing and DICER1 function. Nat Genet 41: 365-370, 2009.

6. Hill DA, Ivanovich J, Priest JR, Gurnett CA, Dehner LP, Desruisseau D, Jarzembowski JA, Wikenheiser-Brokamp KA, Suarez BK, Whelan AJ, et al: DICER1 mutations in familial pleuropulmonary blastoma. Science 325: 965, 2009.

7. Torrezan GT, Ferreira EN, Nakahata AM, Barros BD, Castro MT, Correa BR, Krepischi AC, Olivieri EH, Cunha IW, Tabori U, et al: Recurrent somatic mutation in DROSHA induces microRNA profile changes in Wilms tumour. Nat Commun 5: 4039, 2014

8. Kumar MS, Lu J, Mercer KL, Golub TR and Jacks T: Impaired microRNA processing enhances cellular transformation and tumorigenesis. Nat Genet 39: 673-677, 2007.

9. O'Donnell KA, Wentzel EA, Zeller KI, Dang CV and Mendell JT: c-Myc-regulated microRNAs modulate E2F1 expression. Nature 435: 839-843, 2005

10. Giannakakis A, Sandaltzopoulos R, Greshock J, Liang S, Huang J, Hasegawa K, Li C, O'Brien-Jenkins A, Katsaros D, Weber BL, et al: miR-210 links hypoxia with cell cycle regulation and is deleted in human epithelial ovarian cancer. Cancer Biol Ther 7: 255-264, 2008.

11. Zhang L, Volinia S, Bonome T, Calin GA, Greshock J, Yang N, Liu CG, Giannakakis A, Alexiou P, Hasegawa K, et al: Genomic and epigenetic alterations deregulate microRNA expression in human epithelial ovarian cancer. Proc Natl Acad Sci USA 105 7004-7009, 2008.

12. Sampath D, Liu C, Vasan K, Sulda M, Puduvalli VK, Wierda WG and Keating MJ: Histone deacetylases mediate the silencing of miR-15a, miR-16, and miR-29b in chronic lymphocy tic leukemia. Blood 119: 1162-1172, 2012.

13. Calin GA, Dumitru CD, Shimizu M, Bichi R, Zupo S, Noch E, Aldler H, Rattan S, Keating M, Rai K, et al: Frequent deletions and down-regulation of micro-RNA genes miR15 and miR16 at 13q14 in chronic lymphocytic leukemia. Proc Natl Acad Sci USA 99: 15524-15529, 2002.

14. Calin GA, Ferracin M, Cimmino A, Di Leva G, Shimizu M, Wojcik SE, Iorio MV, Visone R, Sever NI, Fabbri M, et al: A microRNA signature associated with prognosis and progression in chronic lymphocytic leukemia. N Engl J Med 353: 1793-1801, 2005.

15. Yang W, Chendrimada TP, Wang Q, Higuchi M, Seeburg PH, Shiekhattar R and Nishikura K: Modulation of microRNA processing and expression through RNA editing by ADAR deaminases. Nat Struct Mol Biol 13: 13-21, 2006.
16. Hanahan D and Weinberg RA: Hallmarks of cancer: the next generation. Cell 144: 646-674, 2011.

17. Chang CH, Qiu J, O'Sullivan D, Buck MD, Noguchi T, Curtis JD, Chen Q, Gindin M, Gubin MM, van der Windt GJ, et al: Metabolic competition in the tumor microenvironment is a driver of cancer progression. Cell 162: 1229-1241, 2015.

18. Huang G, Nishimoto K, Zhou Z, Hughes D and Kleinerman ES: miR-20a encoded by the miR-17-92 cluster increases the metastatic potential of osteosarcoma cells by regulating Fas expression. Cancer Res 72: 908-916, 2012.

19. Hong L, Lai M, Chen M, Xie C, Liao R, Kang YJ, Xiao C, Hu WY, Han J and Sun P: The miR-17-92 cluster of microRNAs confers tumorigenicity by inhibiting oncogene-induced senescence. Cancer Res 70: 8547-8557, 2010.

20. Si ML, Zhu S, Wu H, Lu Z, Wu F and Mo YY: miR-21-mediated tumor growth. Oncogene 26: 2799-2803, 2007.

21. Seike M, Goto A, Okano T, Bowman ED, Schetter AJ, Horikawa I, Mathe EA, Jen J, Yang P, Sugimura H, et al: MiR-21 is an EGFR-regulated anti-apoptotic factor in lung cancer in never-smokers. Proc Natl Acad Sci USA 106: 12085-12090, 2009.

22. Chan JA, Krichevsky AM and Kosik KS: MicroRNA-21 is an antiapoptotic factor in human glioblastoma cells. Cancer Res 65: 6029-6033, 2005.

23. Özata DM, Caramuta S, Velázquez-Fernández D, Akçakaya P, Xie H, Höög A, Zedenius J, Bäckdahl M, Larsson C and Lui WO: The role of microRNA deregulation in the pathogenesis of adrenocortical carcinoma. Endocr Relat Cancer 18: 643-655, 2011

24. Zhang J and Ma L: MicroRNA control of epithelial-mesenchymal transition and metastasis. Cancer Metastasis Rev 31: 653-662, 2012.

25. Yao Q, Cao S, Li C, Mengesha A, Kong B and Wei M: Micro-RNA-21 regulates TGF- $\beta$-induced myofibroblast differentiation by targeting PDCD4 in tumor-stroma interaction. Int J Cancer 128: 1783-1792, 2011.

26. Eis PS, Tam W, Sun L, Chadburn A, Li Z, Gomez MF, Lund E and Dahlberg JE: Accumulation of miR-155 and BIC RNA in human B cell lymphomas. Proc Natl Acad Sci USA 102: 3627-3632, 2005

27. Xie Y, Todd NW, Liu Z, Zhan M, Fang H, Peng H, Alattar M, Deepak J, Stass SA and Jiang F: Altered miRNA expression in sputum for diagnosis of non-small cell lung cancer. Lung Cancer 67: 170-176, 2010.

28. Volinia S, Calin GA, Liu CG, Ambs S, Cimmino A, Petrocca F, Visone R, Iorio M, Roldo C, Ferracin M, et al: A microRNA expression signature of human solid tumors defines cancer gene targets. Proc Natl Acad Sci USA 103: 2257-2261, 2006.

29. Ovcharenko D, Kelnar K, Johnson C, Leng N and Brown D: Genome-scale microRNA and small interfering RNA screens identify small RNA modulators of TRAIL-induced apoptosis pathway. Cancer Res 67: 10782-10788, 2007.

30. Kong W, He L, Richards EJ, Challa S, Xu CX, Permuth-Wey J, Lancaster JM, Coppola D, Sellers TA, Djeu JY, et al: Upregulation of miRNA-155 promotes tumour angiogenesis by targeting VHL and is associated with poor prognosis and triple-negative breast cancer. Oncogene 33: 679-689, 2014.

31. Robertson ED, Wasylyk C, Ye T, Jung AC and Wasylyk B: The oncogenic MicroRNA Hsa-miR-155-5p targets the transcription factor ELK3 and links it to the hypoxia response. PLoS One 9: e113050, 2014

32. Calin GA, Liu CG, Sevignani C, Ferracin M, Felli N, Dumitru CD, Shimizu M, Cimmino A, Zupo S, Dono M, et al: MicroRNA profiling reveals distinct signatures in B cell chronic lymphocytic leukemias. Proc Natl Acad Sci USA 101: 11755-11760, 2004.

33. Bandi N, Zbinden S, Gugger M, Arnold M, Kocher V, Hasan L, Kappeler A, Brunner T and Vassella E: $m i R-15 a$ and $m i R-16$ are implicated in cell cycle regulation in a $\mathrm{Rb}$-dependent manner and are frequently deleted or down-regulated in non-small cell lung cancer. Cancer Res 69: 5553-5559, 2009.

34. Porkka KP, Ogg EL, Saramäki OR, Vessella RL, Pukkila H, Lähdesmäki H, van Weerden WM, Wolf M, Kallioniemi OP, Jenster G, et al: The miR-15a-miR-16-1 locus is homozygously deleted in a subset of prostate cancers. Genes Chromosomes Cancer 50: 499-509, 2011.

35. Bonci D, Coppola V, Musumeci M, Addario A, Giuffrida R, Memeo L, D'Urso L, Pagliuca A, Biffoni M, Labbaye C, et al: The miR-15a-miR-16-1 cluster controls prostate cancer by targeting multiple oncogenic activities. Nat Med 14: 1271-1277, 2008

36. Cimmino A, Calin GA, Fabbri M, Iorio MV, Ferracin M, Shimizu M, Wojcik SE, Aqeilan RI, Zupo S, Dono M, et al: $m i R-15$ and $m i R-16$ induce apoptosis by targeting BCL2. Proc Natl Acad Sci USA 102: 13944-13949, 2005. 
37. Patterson EE, Holloway AK, Weng J, Fojo T and Kebebew E: MicroRNA profiling of adrenocortical tumors reveals miR-483 as a marker of malignancy. Cancer 117: 1630-1639, 2011.

38. Zhang Z, Sun H, Dai H, Walsh RM, Imakura M, Schelter J, Burchard J, Dai X, Chang AN, Diaz RL, et al: MicroRNA miR-210 modulates cellular response to hypoxia through the MYC antagonist MNT. Cell Cycle 8: 2756-2768, 2009.

39. Chabre O, Libé R, Assie G, Barreau O, Bertherat J, Bertagna X, Feige JJ and Cherradi N: Serum miR-483-5p and miR-195 are predictive of recurrence risk in adrenocortical cancer patients. Endocr Relat Cancer 20: 579-594, 2013.

40. Caramuta S, Lee L, Ozata DM, Akçakaya P, Xie H, Höög A, Zedenius J, Bäckdahl M, Larsson C and Lui WO: Clinical and functional impact of TARBP2 over-expression in adrenocortical carcinoma. Endocr Relat Cancer 20: 551-564, 2013.

41. Gillis AJ, Stoop HJ, Hersmus R, Oosterhuis JW, Sun Y, Chen C, Guenther S, Sherlock J, Veltman I, Baeten J, et al High-throughput microRNAome analysis in human germ cell tumours. J Pathol 213: 319-328, 2007.

42. Gu S, Cheung HH, Lee TL, Lu G, Poon WS and Chan WY: Molecular mechanisms of regulation and action of microRNA-199a in testicular germ cell tumor and glioblastomas. PLoS One 8: e83980, 2013.

43. Kiuchi T, Koga H, Kawamoto M, Shoji K, Sakai H, Arai Y, Ishihara G, Kawaoka S, Sugano S, Shimada T, et al: A single female-specific piRNA is the primary determiner of sex in the silkworm. Nature 509: 633-636, 2014.

44. Gou LT, Dai P, Yang JH, Xue Y, Hu YP, Zhou Y, Kang JY, Wang X, Li H, Hua MM, et al: Pachytene piRNAs instruct massive mRNA elimination during late spermiogenesis. Cell Res 24: 680-700, 2014.

45. Rouget C, Papin C, Boureux A, Meunier AC, Franco B Robine N, Lai EC, Pelisson A and Simonelig M: Maternal mRNA deadenylation and decay by the piRNA pathway in the early Drosophila embryo. Nature 467: 1128-1132, 2010
46. Qiao D, Zeeman AM, Deng W, Looijenga LH and Lin H: Molecular characterization of hiwi, a human member of the piwi gene family whose overexpression is correlated to seminomas. Oncogene 21: 3988-3999, 2002

47. Suzuki R, Honda S and Kirino Y: PIWI expression and function in cancer. Front Genet 3: 204, 2012.

48. Sun G, Wang Y, Sun L, Luo H, Liu N, Fu Z and You Y: Clinical significance of Hiwi gene expression in gliomas. Brain Res 1373: 183-188, 2011.

49. Hashim A, Rizzo F, Marchese G, Ravo M, Tarallo R, Nassa G, Giurato G, Santamaria G, Cordella A, Cantarella C, et al: RNA sequencing identifies specific PIWI-interacting small non-coding RNA expression patterns in breast cancer. Oncotarget 5: 9901-9910, 2014.

50. Chu H, Hui G, Yuan L, Shi D, Wang Y, Du M, Zhong D, Ma L, Tong N, Qin C, et al: Identification of novel piRNAs in bladder cancer. Cancer Lett 356: 561-567, 2015.

51. Yan H, Wu QL, Sun CY, Ai LS, Deng J, Zhang L, Chen L, Chu ZB, Tang B, Wang K, et al: piRNA-823 contributes to tumorigenesis by regulating de novo DNA methylation and angiogenesis in multiple myeloma. Leukemia 29: 196-206, 2015.

52. Ravo M, Cordella A, Rinaldi A, Bruno G, Alexandrova E, Saggese P, Nassa G, Giurato G, Tarallo R, Marchese G, et al: Small non-coding RNA deregulation in endometrial carcinogenesis. Oncotarget 6: 4677-4691, 2015.

53. Cheng J, Deng H, Xiao B, Zhou H, Zhou F, Shen Z and Guo J: piR-823, a novel non-coding small RNA, demonstrates in vitro and in vivo tumor suppressive activity in human gastric cancer cells. Cancer Lett 315: 12-17, 2012. 